\title{
Identification and characterization of serine acetyltransferase encoded by the Mycobacterium tuberculosis Rv2335 gene
}

\author{
JUANJUAN QIU $^{1,2}$, DAIQING WANG ${ }^{2}$, YUFANG MA ${ }^{2}$, TAO JIANG ${ }^{1}$ and YI XIN ${ }^{1}$ \\ Departments of ${ }^{1}$ Biotechnology and ${ }^{2}$ Biochemistry and Molecular Biology, \\ Dalian Medical University, Dalian 116044, P.R. China
}

Received December 13, 2012; Accepted February 11, 2013

DOI: $10.3892 /$ ijmm.2013.1298

\begin{abstract}
Serine acetyltransferase (CysE) is the first enzyme involved in the two-step enzymatic pathway of L-cysteine biosynthesis in bacteria and plants, but not in humans. CysE catalyzes the biosynthesis of $O$-acetyl-L-serine and CoA from L-serine (L-Ser) and acetyl-CoA (AcCoA). Mycobacterium tuberculosis (M. tuberculosis) Rv2335 was predicted as the cys $E$ gene encoding serine acetyltransferase. In this study, the M.tuberculosis Rv2335 gene was cloned and the CysE protein was expressed in E. coli BL21 (DE3). The M. tuberculosis CysE protein was purified by $\mathrm{Ni}^{2+}$ affinity chromatography and confirmed by SDS-PAGE, western blotting and mass spectrometry. The serine acetyltransferase activity of the M. tuberculosis CysE protein was detected using Ellman's reagent. $M$. tuberculosis $\mathrm{CysE}$ displayed optimal activity at $\mathrm{pH} 7.5$ and $37^{\circ} \mathrm{C}$. The Michaelis constant for AcCoA and L-Ser was $0.0513 \pm 0.0050$ and $0.0264 \pm 0.0006 \mathrm{mM}$, respectively. The maximum velocity $\left(\mathrm{V}_{\max }\right)$ for CysE was $0.0073 \pm 0.0005 \mathrm{mM} / \mathrm{min}$. The CysE assay and the determination of the kinetic parameters of M. tuberculosis CysE may be helpful for screening its inhibitors in anti-tuberculosis drug discovery.
\end{abstract}

\section{Introduction}

Although tuberculosis (TB) is an ancient disease resulting from infection with Mycobacterium tuberculosis (M. tuberculosis), it remains a great threat to both individual and public health throughout the world. It is reported that approximately onethird of the world's population has been latently infected (1).

Correspondence to: Professor Yi Xin, Department of Biotechnology, Dalian Medical University, 9 W. Lvshun South Road, Dalian 116044, P.R. China

E-mail: xinyi20120908@gmail.com

Abbreviations: DTNB, 5,5'-dithio-bis-(2-nitrobenzoic acid); EDTA, ethylendiaminetetraacetic acid; IPTG, isopropyl $\beta$-D-thiogalactopyranoside; PMSF, phenymethylsulfonyl fluoride; NIH, National Institutes of Health

Key words: Mycobacterium tuberculosis, L-cysteine biosynthesis, serine acetyltransferase, CysE, Rv2335, kinetic parameters
The prevalence of human immunodeficiency virus has enhanced the spread of multi-drug resistant and extensively drug resistant tuberculosis strains, and the morbidity and mortality of TB have been rising yearly without much curative success using existing anti-TB drugs (2-4). Therefore, it is a matter of urgency to discover targets for new anti-TB drugs. Serine acetyltransferase (CysE) is involved in the biosynthesis of cysteine, which catalyzes the conversion of acetyl-CoA (AcCoA) and L-serine (L-Ser) to CoA and $O$-acetyl-L-serine (OAS) $(5,6)$. This reaction is the first step in the two-step biosynthesis of L-cysteine in microorganisms and plants $(7,8)$. Because of the differing pathways for cysteine anabolism in humans and microorganisms (9), serine acetyltransferase exists only in microorganisms. An ideal drug target should be unique to the pathogen, thus $M$. tuberculosis serine acetyltransferase is regarded as a potential drug target $(10,11)$.

The CysE protein has been purified and characterized from certain bacteria, such as Escherichia coli $(6,12,13)$, Salmonella typhimurium $(5,14)$ and Haemophilus influenzae (15). Bioinformatic analyses have shown that $M$. tuberculosis Rv2335 is homologous to E. coli CysE, S. typhimurium CysE and H. influenzae CysE. Therefore, M. tuberculosis Rv2335 (GenBank accession no. CAB06152.1) could be a cysE gene that encodes the CysE protein.

In this study, we cloned and expressed the M. tuberculosis cysE (Rv2335) gene in E. coli and characterized the purified M.tuberculosis CysE protein. The kinetic studies on M.tuberculosis CysE allow for the screening of its inhibitors in the development of anti-TB drugs.

\section{Materials and methods}

Microorganisms and plasmids. E. coli NovaBlue and E. coli BL21 (DE3) (Novagen) were maintained as the hosts for cloning and expression, respectively. The cloning plasmid pMD18-T (Takara) with the ampicillin resistance gene was utilized to clone and sequence the target gene or DNA fragment. The expression vector pET29b (Novagen) carrying the kanamycin resistance gene was used for gene expression in E. coli. M. tuberculosis H37Rv genomic DNA was supplied by Colorado State University via an NIH contract.

Cloning the cysE (Rv2335) gene from M. tuberculosis H37Rv genomic DNA. The M. tuberculosis cysE gene was amplified 
Table I. Specific activity and kinetic parameters of M. tuberculosis CysE.

\begin{tabular}{lccccc} 
& $\begin{array}{c}\text { Specific activity } \\
\left(\mu \mathrm{mol} \cdot \mathrm{min}^{-1} \cdot \mathrm{mg}^{-1}\right)\end{array}$ & $\begin{array}{c}\mathrm{V}_{\text {max }} \\
\left(\mathrm{mM} \cdot \mathrm{min}^{-1}\right)\end{array}$ & $\begin{array}{c}\mathrm{K}_{\mathrm{AcCoA}} \\
(\mathrm{mM})\end{array}$ & $\begin{array}{c}\mathrm{K}_{\text {ser }} \\
(\mathrm{mM})\end{array}$ & $\begin{array}{c}\mathrm{K}_{\text {cat }} \\
\left(\mathrm{sec}^{-1}\right)\end{array}$ \\
\hline M. tuberculosis CysE & $10.66 \pm 0.44$ & $0.0073 \pm 0.0005$ & $0.0513 \pm 0.0050$ & $0.0264 \pm 0.0006$ & $81.36 \pm 5.22$ \\
\hline
\end{tabular}

The activity was determined under specific conditions. The $\mathrm{K}_{\mathrm{m}}$ and $\mathrm{V}_{\max }$ of CysE were determined under the optimal conditions by double reciprocal plot. CysE, serine acetyltransferase. $V_{\max }$, maximum velocity; $\mathrm{K}_{\mathrm{ser}}, \mathrm{K}_{\mathrm{m}}$ for L-serine; $\mathrm{K}_{\mathrm{AcCoA}}, \mathrm{K}_{\mathrm{m}}$ for acetyl-CoA.

from M. tuberculosis H37Rv genomic DNA using the following set of primers: cysE forward, 5'-AACATATGCT GACGGCCATGCGGG-3' (underlined sequence is the NdeI site) and cysE reverse primer, 5'-AACTCGAGGATCGAG AAGTCCTCGCCG-3' (underlined sequence is the XhoI site). The amplified PCR product was ligated into pMD18-T to generate the plasmid pMD18-cysE, which was transformed into $E$. coli NovaBlue. The positive recombinant plasmid pMD18-cysE was confirmed by digestion with restriction endonucleases (EcoRI) and subsequently sequenced. The $c y s \mathrm{E}$ gene was subcloned into the NdeI and XhoI sites of pET29b, yielding the expression vector pET29b-cysE.

Expression, purification and identification of CysE protein. The plasmid pET29b-cysE was transformed into E. coli BL21 (DE3). BL21 (DE3)/pET29b-cysE culture was induced with $1 \mathrm{mM}$ IPTG at $37^{\circ} \mathrm{C}$ for $3 \mathrm{~h}$. The cells were harvested and suspended in lysis buffer $(20 \mathrm{mM}$ Tris- $\mathrm{HCl} \mathrm{pH} 8.0,100 \mathrm{mM}$ $\mathrm{NaCl}, 25 \mathrm{mM} \mathrm{MgCl}_{2}, 5 \%$ (v/v) glycerol, $1 \mathrm{mM}$ EDTA, $1 \mathrm{mM}$ $\beta$-mercaptoethanol and $1 \mathrm{mM}$ PMSF). The cells were homogenized by sonication and the cell lysate was centrifuged at $20,000 \mathrm{x} g$ for $20 \mathrm{~min}$. The supernatant was then loaded onto a 1-ml Ni-NTA agarose column (Qiagen). The column was then washed with $20 \mathrm{ml}$ of wash buffer $(20 \mathrm{mM}$ Tris- $\mathrm{HCl} \mathrm{pH} 8.0$, $500 \mathrm{mM} \mathrm{NaCl}, 20 \%$ glycerol, $60 \mathrm{mM}$ imidazole and $1 \mathrm{mM}$ PMSF), and the CysE protein with a His-tag at its C-terminus was eluted with $10 \mathrm{ml}$ of elution buffer $(20 \mathrm{mM}$ Tris- $\mathrm{HCl}$ pH 8.0, $500 \mathrm{mM} \mathrm{NaCl}, 20 \%$ glycerol, $300 \mathrm{mM}$ imidazole and $1 \mathrm{mM}$ PMSF) and examined by SDS-PAGE and western blotting. The purified CysE protein was further confirmed by matrix-assisted laser desorption/ionization-time of flight mass spectrometry (MALDI-TOF-MS) (BIG, China).

Enzyme assays. The serine acetyltransferase activity of the CysE protein was determined by monitoring the increase in the absorbance of Ellman's reagent (DTNB) due to its reaction with CoA $(16,17)$. Briefly, a $50-\mu 1$ reaction mixture $(50 \mathrm{mM}$ Tris- $\mathrm{HCl} \mathrm{pH} 7.5,5 \mathrm{mM} \mathrm{MgCl}{ }_{2}, 0.4 \mathrm{mM}$ AcCoA, $2 \mathrm{mM}$ L-Ser and $0.037 \mu \mathrm{g}$ purified CysE protein) in a 96-well microtiter plate was incubated at $37^{\circ} \mathrm{C}$ for $20 \mathrm{~min}$. A blank control without L-Ser and AcCoA, and a positive control containing standard CoA $(0.2 \mathrm{mM})$ only were included. The reaction was terminated with $50 \mu \mathrm{l}$ of stop solution $(50 \mathrm{mM}$ Tris- $\mathrm{HCl}$ $\mathrm{pH}$ 7.5, $6 \mathrm{M}$ guanidine hydrochloride). Fifty microliters of Ellman's reagent (50 mM Tris- $\mathrm{HCl} \mathrm{pH}$ 7.5, $0.2 \mathrm{mM}$ DTNB and $1 \mathrm{mM}$ EDTA) was added to the reaction mixture. The mixture was incubated at room temperature for $10 \mathrm{~min}$. The absorbance values were obtained using a microplate reader (Multiskan Ascent; Thermo Scientific) at a wavelength of
$405 \mathrm{~nm}$ (18). One unit of specific enzyme activity was defined as $1 \mu \mathrm{mol}$ of CoA-SH produced by $1 \mathrm{mg}$ protein/min under specific conditions.

Characterization of $M$. tuberculosis CysE. The maximum velocity $\left(\mathrm{V}_{\text {max }}\right)$ and Michaelis constant $\left(\mathrm{K}_{\mathrm{m}}\right)$ of M. tuberculosis CysE were measured by a colorimetric assay coupled with DTNB. Based on the concentration curves and time-course curves of CysE, the range of CysE initial velocities was measured. The concentration curves of CysE were plotted by measuring the reaction velocities at varying CysE concentrations and reaction times. The reactions were performed in $50 \mathrm{mM}$ Tris- $\mathrm{HCl}$ buffer ( $\mathrm{pH} 7.5$ ) containing AcCoA, L-Ser and different concentrations of purified CysE (0.74, 1.48, $2.22,2.96$ and $3.70 \mu \mathrm{g} / \mathrm{ml}$ ) at $37^{\circ} \mathrm{C}$ for 5,15 and $25 \mathrm{~min}$. The time-course curves were plotted by measuring the amount of CoA at different reaction times $(5,10,15,20$ and $25 \mathrm{~min})$ and different concentrations of CysE $(0.74,2.22$ and $3.70 \mu \mathrm{g} / \mathrm{ml})$ at $37^{\circ} \mathrm{C}$. To further characterize the $\mathrm{CysE}$, the effect of $\mathrm{pH}$, temperature, and $\mathrm{Mg}^{2+}$ concentration on $\mathrm{CysE}$ were evaluated by measuring CysE activity in different $\mathrm{pH}$ buffers (3-11), at various temperatures $\left(16-80^{\circ} \mathrm{C}\right)$ and concentrations of $\mathrm{Mg}^{2+}$ (0-20 mM), respectively.

In dual-substrate reactions, the steady-state kinetic parameters $\mathrm{K}_{\mathrm{m}}$ and $\mathrm{V}_{\max }$ were calculated by double reciprocal plots prepared by varying the concentration of one substrate while the second substrate was in excess under optimal conditions.

\section{Results}

Cloning of the M.tuberculosis cysE gene. The PCR product for the cysE gene was obtained from the genomic DNA of M. tuberculosis H37Rv (Fig. 1A). The size of the PCR product (cysE gene plus NdeI and XhoI recognition sites) was 700 bp.

Expression, purification and identification of the CysE protein. The soluble $M$. tuberculosis CysE protein was expressed in $E$. coli BL21 (DE3) by induction with $1 \mathrm{mM}$ IPTG. The purified CysE protein was detected by SDS-PAGE (Fig. 1B) and western blotting (Fig. 1C). The band of the CysE protein appeared at $30 \mathrm{kDa}$, which was higher than the theoretical molecular mass $(24.6 \mathrm{kDa})$ of the CysE protein. The purified CysE protein was further confirmed by MALDI-TOF-MS analysis (data not shown).

Serine acetyltransferase activity of $M$. tuberculosis CysE protein. The serine acetyltransferase activity of M.tuberculosis CysE protein was detected. The specific activity of the serine acetyltransferase was $10.66 \pm 0.44 \mu \mathrm{mol} / \mathrm{min} / \mathrm{mg}$ (Table I). 

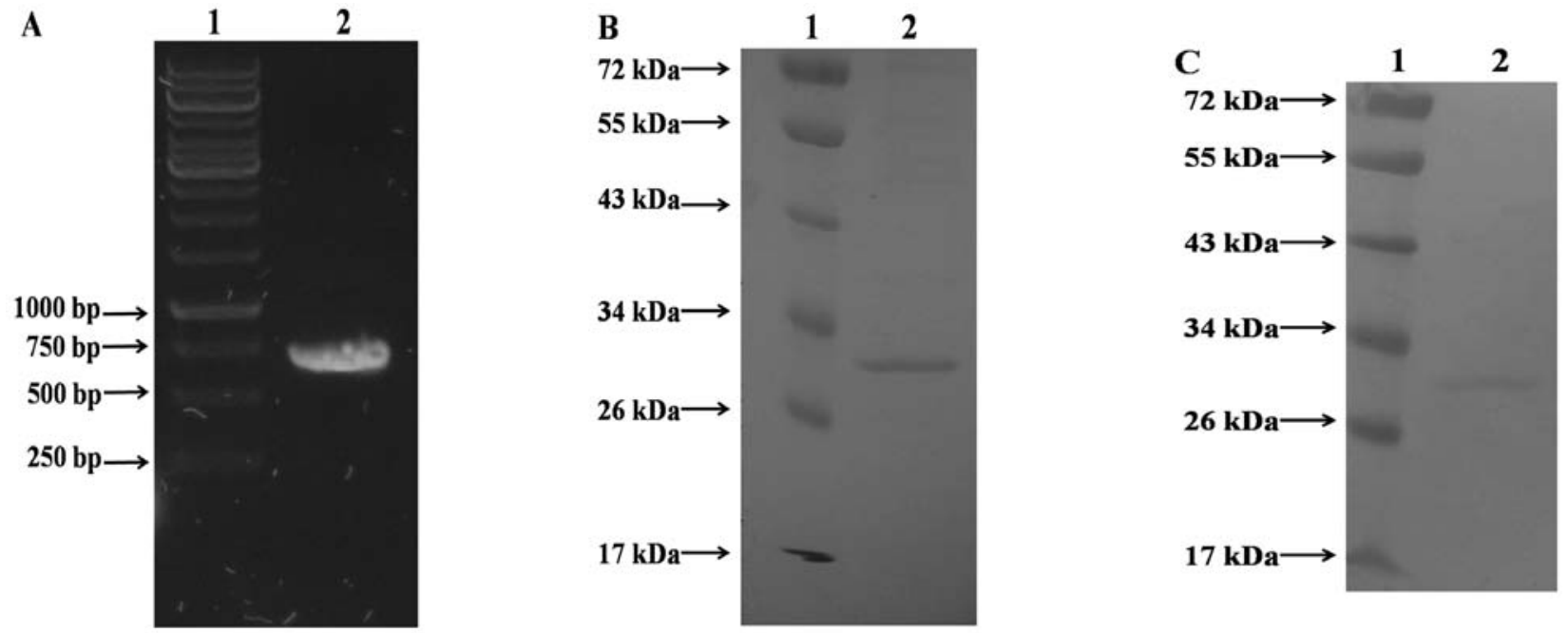

Figure 1. Analysis of cysE PCR products and purified M.tuberculosis CysE protein. (A) Electrophoretic analysis of cysE PCR product by $1 \%$ agarose. Lane 1 , GeneRuler $1 \mathrm{~kb}$ DNA ladder (Fermentas); lane 2, PCR product of cysE gene amplified from M. tuberculosis H37Rv genomic DNA. (B) SDS-PAGE analysis of the purified CysE protein. Lane 1, PageRuler pre-stained protein ladder (Fermentas); lane 2, the purified CysE protein. (C) Western blotting analysis of purified CysE protein. Lane 1, PageRuler pre-stained protein ladder; lane 2, the purified CysE protein.
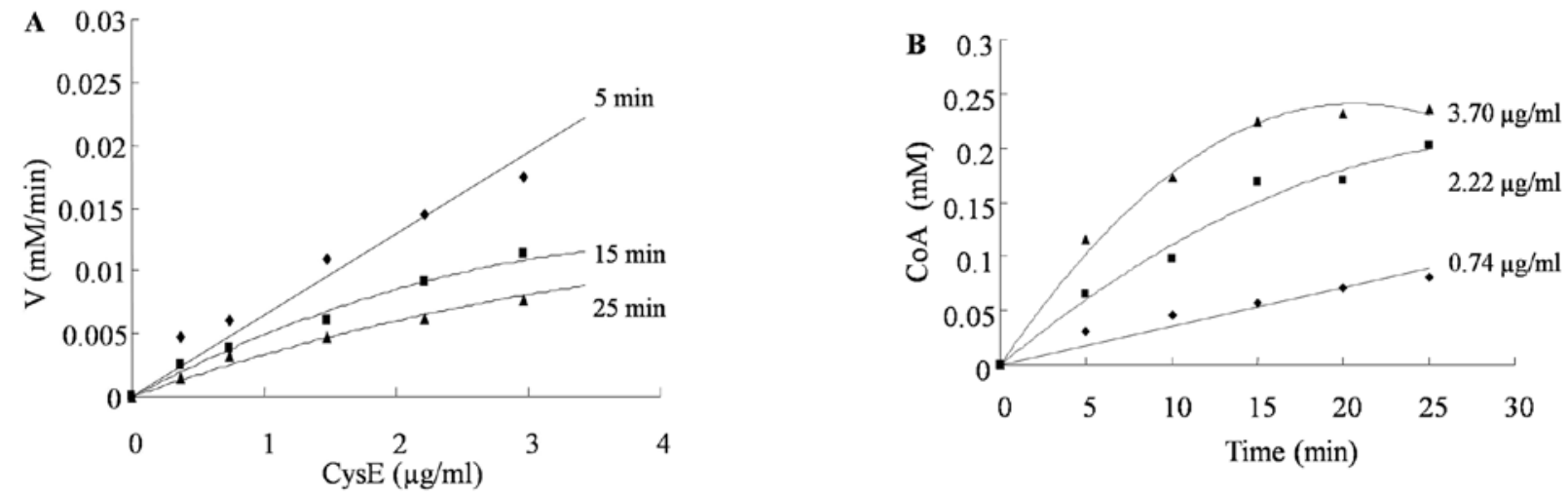

Figure 2. (A) CysE concentration curves and (B) time-course curves. (A) Reaction velocity vs. concentration of CysE at different reaction times: $\bullet 5$ min; $\boldsymbol{\nabla}$ $15 \mathrm{~min} ; \mathbf{\wedge}, 25 \mathrm{~min}$. (B) Concentration of CoA vs. reaction time at different concentrations of CysE: $\bullet, 0.74 \mu \mathrm{g} / \mathrm{ml} ; \mathbf{\square}, 2.22 \mu \mathrm{g} / \mathrm{ml} ; \mathbf{\Lambda}, 3.70 \mu \mathrm{g} / \mathrm{ml}$.

Characterization of $M$. tuberculosis CysE. The reaction velocity was proportional to the concentration of $M$. tuberculosis CysE when the reaction time was 5 min (Fig. 2A). At 15 or 25 min reaction times, the reaction velocity gradually slowed and became non-linear with the CysE concentration. Therefore, the initial velocity of CysE was within $5 \mathrm{~min}$.

Within a maximum concentration limit of $0.74 \mu \mathrm{g} / \mathrm{ml}$, the concentration of $\mathrm{CoA}$ was proportional to the reaction time (Fig. 2B). As the CysE concentration reached 2.22 or $3.70 \mu \mathrm{g} /$ $\mathrm{ml}$, the rate of $\mathrm{CoA}$ formation gradually decreased with reaction time. The optimal concentration for characterizing CysE was $0.74 \mu \mathrm{g} / \mathrm{ml}$.

The CysE activity was determined at varying $\mathrm{pHs}$ with appropriate buffer systems (3-11) after the initial velocity and optimal CysE protein concentration were set (Fig. 3A). The optimal $\mathrm{pH}$ for $\mathrm{CysE}$ was 7.5. The optimal temperature for CysE was investigated from 16 to $80^{\circ} \mathrm{C}$ (Fig. 3B), with the highest activity observed as the temperature reached $37^{\circ} \mathrm{C}$. The catalytic activity of CysE was not significantly changed by varying the $\mathrm{Mg}^{2+}$ concentration (Fig. 3C), indicating that $\mathrm{Mg}^{2+}$ had no effect on the CysE activity.
The steady-state kinetic constants were determined under the optimal conditions and the initial velocity by a double reciprocal plot (Fig. 4). The $\mathrm{V}_{\max }$ value of CysE was $0.0073 \pm 0.0005 \mathrm{mM} / \mathrm{min}$. The $\mathrm{K}_{\mathrm{m}}$ of CysE against AcCoA was $0.0513 \pm 0.0050 \mathrm{mM}$, while the $\mathrm{K}_{\mathrm{m}}$ value of L-Ser was $0.0264 \pm 0.0006 \mathrm{mM}$ (Table I).

\section{Discussion}

Serine acetyltransferase is an enzyme involved in cysteine biosynthesis, and it plays an important role in the growth of M. tuberculosis (10). In addition, this enzyme only exists in microorganisms and plants (9), making serine acetyltransferase a potential anti-TB drug target.

M. tuberculosis Rv2335 is predicted to be a cys $\mathrm{E}$ gene encoding serine acetyltransferase. Bioinformatic analyses have shown that the $M$. tuberculosis Rv2335 protein is $45 \%$ identical to E. coli CysE, S. typhimurium CysE and H. influenzae CysE using the Basic Local Alignment Search Tool (BLAST). Serine acetyltransferase is a member of the hexapeptide acetyltransferase family (19). This protein family has 

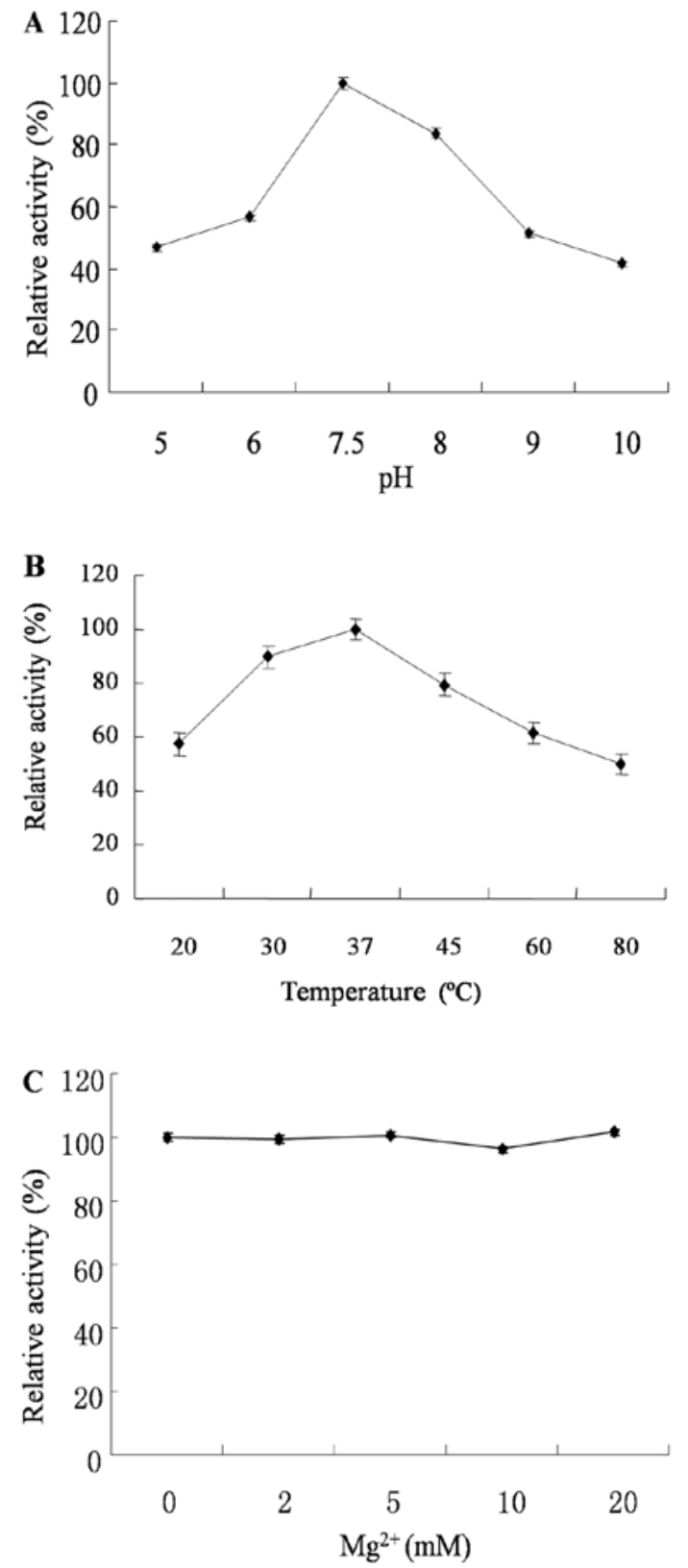

Figure 3. Determination of the optimal conditions for M. tuberculosis CysE activity. (A) $\mathrm{pH}$ curve; (B) temperature curve; (C) $\mathrm{Mg}^{2+}$ concentration curve.

a conserved active left-handed- $\beta$-helix $(\mathrm{L} \beta \mathrm{H})$ domain, which is composed of a six-peptide ([LIV]-[GAED]-X2[STAV]-X) tandem repeat $(15,20,21)$. The M. tuberculosis Rv2335 protein contained the tandem repeat and showed $\mathrm{L} \beta \mathrm{H}$ structure when modeled using the NCBI Conserved Domain Search (data not shown)

To identify the function of M. tuberculosis CysE, the M. tuberculosis cysE (Rv2335) gene was amplified with high fidelity DNA polymerase, and the soluble CysE protein was expressed in E. coli. SDS-PAGE and western blotting showed that the molecular weight of the expressed CysE protein $(\sim 30 \mathrm{kDa})$ was higher than predicted. This finding could be due to the auxiliary fusion of six histidines to the recombinant M. tuberculosis CysE protein generated from the pET29b vector. The six consecutive histidines impart a strong positive
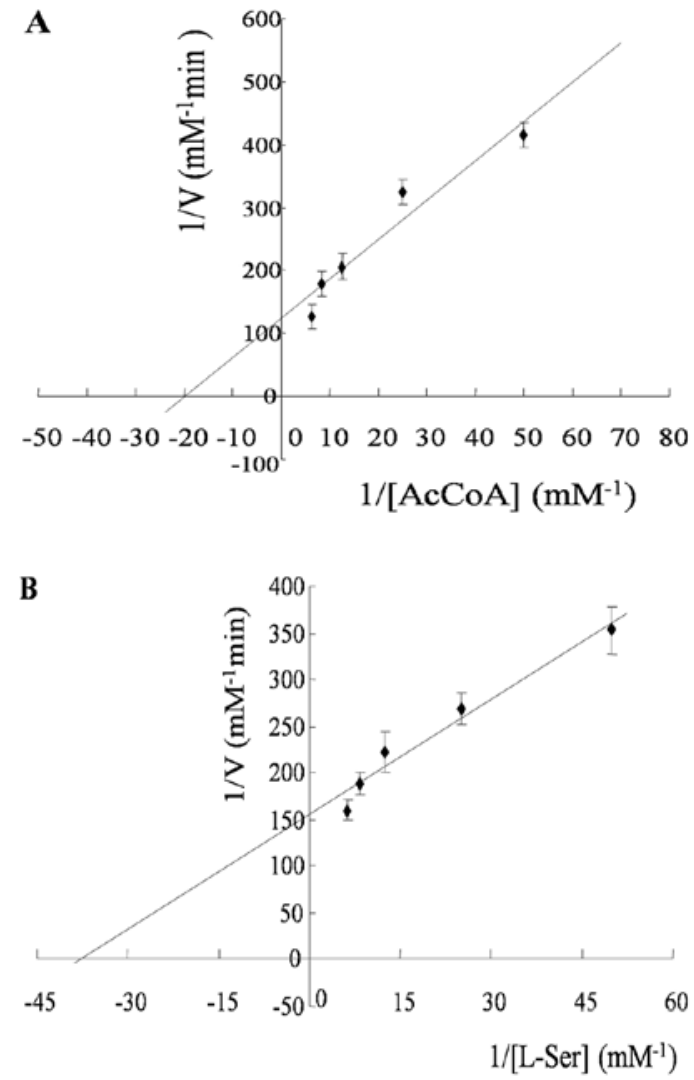

Figure 4. Determination of $\mathrm{V}_{\max }$ and $\mathrm{K}_{\mathrm{m}}$ values for $M$. tuberculosis CysE. (A) $\mathrm{V}_{\max }$ and $\mathrm{K}_{\mathrm{m}}$ values for AcCoA from a double reciprocal plot; (B) $\mathrm{V}_{\max }$ and $\mathrm{K}_{\mathrm{m}}$ values for L-Ser from a double reciprocal plot.

charge that may retard the mobility of the CysE protein in SDS-PAGE.

As indicated in Table I, M. tuberculosis CysE demonstrated serine acetyltransferase activity of $10.66 \mu \mathrm{mol} / \mathrm{min} / \mathrm{mg}$. The specific activity of $E$. coli serine acetyltransferase has been reported as $71.6 \mu \mathrm{mol} / \mathrm{min} / \mathrm{mg}$ (22). The specific activity of M. tuberculosis CysE is lower than that of E. coli CysE, possibly because of the different methods of purification. M. tuberculosis CysE exhibited its highest acetyltransferase activity at $\mathrm{pH} 7.5$ and $37^{\circ} \mathrm{C}$. The optimal $\mathrm{pH}$ is consistent with those reported for other bacteria, but the optimal temperature is different from those reported for other bacteria such as S. typhimurium $\left(25^{\circ} \mathrm{C}\right)(14)$, E. coli $\left(25^{\circ} \mathrm{C}\right)(12)$ and $H$. influenzae $\left(25^{\circ} \mathrm{C}\right)(15)$. The $\mathrm{K}_{\mathrm{m}}$ for L-serine $\left(\mathrm{K}_{\mathrm{ser}}\right)$ of M.tuberculosis CysE $(0.026 \mathrm{mM})$ is lower than the $\mathrm{K}_{\text {ser }}$ of $S$. typhimurium CysE $(0.7 \mathrm{mM})$ and E. coli CysE $(1.17 \mathrm{mM})(12,23)$. The $\mathrm{K}_{\mathrm{m}}$ for AcCoA $\left(\mathrm{K}_{\mathrm{AcCoA}}\right)$ of M. tuberculosis CysE $(0.051 \mathrm{mM})$ is also lower than that of $S$. typhimurium CysE $(0.1 \mathrm{mM})$ and E. coli CysE $(0.2 \mathrm{mM})(12,23)$. In the present study, the $\mathrm{K}_{\text {AcCoA }}$ of M. tuberculosis CysE was $0.051 \mathrm{mM}$, while the $\mathrm{K}_{\text {ser }}$ was $0.026 \mathrm{mM}$. This finding suggests that CysE had higher affinity for L-Ser than AcCoA, and CysE was bound more easily to L-Ser than to AcCoA in M. tuberculosis. Cysteine is reported to inhibit the activity of serine acetyltransferase in its biosynthetic pathway by a feedback mechanism $(7,12,15)$. Furthermore, cysteine was found to bind E. coli $\mathrm{CysE}$ at the serine substrate site rather than at the acetyl-CoA substrate site from the structural study on acetyltransferase (20). This finding indicates that it is preferable to screen and design 
compounds against the L-serine site to inhibit the activity of CysE.

In summary, serine acetyltransferase CysE was encoded by the cysE (Rv2335) gene in M.tuberculosis. We investigated the kinetic parameters and optimal catalytic conditions of CysE using simple and rapid enzyme assays. The CysE assay and kinetic properties of CysE will facilitate the high-throughput screening of inhibitors against CysE. However, there are currently no reports of the crystal structure and active sites of $M$. tuberculosis CysE. The expressed soluble CysE protein will be available to further elucidate its crystal structure and active sites.

\section{Acknowledgements}

This study was supported by a grant from the National Natural Science Foundation of China (31070066) and the National Basic Research Program of China (2012CB518803).

\section{References}

1. Donald PR and van Helden PD: The global burden of tuberculosis - combating drug resistance in difficult times. N Engl J Med 360: 2393-2395, 2009

2. Migliori GB, Matteelli A, Cirillo D and Pai M: Diagnosis of multidrug-resistant tuberculosis and extensively drug-resistant tuberculosis: current standards and challenges. Can J Infect Dis Med Microbiol 19: 169-172, 2008.

3. Harrington M: From HIV to tuberculosis and back again: a tale of activism in 2 pandemics. Clin Infect Dis 50 (Suppl 3): S260-S266, 2010.

4. Cole ST and Riccardi G: New tuberculosis drugs on the horizon. Curr Opin Microbiol 14: 570-576, 2011.

5. Kredich NM, Becker MA and Tomkins GM: Purification and characterization of cysteine synthetase, a bifunctional protein complex, from Salmonella typhimurium. J Biol Chem 244: 2428-2439, 1969.

6. Kredich NM and Tomkins GM: The enzymic synthesis of L-cysteine in Escherichia coli and Salmonella typhimurium. J Biol Chem 241: 4955-4965, 1966.

7. Kredich NM: Biosynthesis of cysteine. In: Escherichia coli and Salmonella typhimurium: Cellular and Molecular Biology. Vol 1. Neidhardt FC, Curtiss R, Ingraham JL, Lin ECC Low KB, Magasanik B, Reznikoff WS, Riley M, Schaechter M and Umberger E (eds). 2nd edition. American Society for Microbiology, Washington D.C., pp514-527, 1996.
8. Hell R: Molecular physiology of plant sulfur metabolism. Planta 202: 138-148, 1997.

9. Meisenberg G and Simmons W: Princples of Medical Biochemistry. Mosby Elsevier, Philadelphia, 2006.

10. Schnell R and Schneider G: Structural enzymology of sulphur metabolism in Mycobacterium tuberculosis. Biochem Biophys Res Commun 396: 33-38, 2010.

11. Raman K, Yeturu K and Chandra N: targetTB: a target identification pipeline for Mycobacterium tuberculosis through an interactome, reactome and genome-scale structural analysis. BMC Syst Biol 2: 109, 2008.

12. Hindson VJ: Serine acetyltransferase of Escherichia coli: substrate specificity and feedback control by cysteine. Biochem $\mathbf{J}$ 375: 745-752, 2003.

13. Mino K, Yamanoue T, Sakiyama T, Eisaki N, Matsuyama A and Nakanishi K: Effects of bienzyme complex formation of cysteine synthetase from Escherichia coli on some properties and kinetics. Biosci Biotechnol Biochem 64: 1628-1640, 2000.

14. Leu LS and Cook PF: Kinetic mechanism of serine transacetylase from Salmonella typhimurium. Biochemistry 33: 2667-2671, 1994.

15. Johnson CM, Huang B, Roderick SL and Cook PF: Kinetic mechanism of the serine acetyltransferase from Haemophilus influenzae. Arch Biochem Biophys 429: 115-122, 2004.

16. Ellman GL: A colorimetric method for determining low concentrations of mercaptans. Arch Biochem Biophys 74: 443-450, 1958.

17. Riddles PW, Blakeley RL and Zerner B: Reassessment of Ellman's reagent. Methods Enzymol 91: 49-60, 1983.

18. Zhou Y, Xin Y, Sha S and Ma Y: Kinetic properties of Mycobacterium tuberculosis bifunctional GlmU. Arch Microbiol 193: 751-757, 2011.

19. Downie JA: The nodL gene from Rhizobium leguminosarum is homologous to the acetyl transferases encoded by lacA and cysE. Mol Microbiol 3: 1649-1651, 1989.

20. Pye VE, Tingey AP, Robson RL and Moody PC: The structure and mechanism of serine acetyltransferase from Escherichia coli. J Biol Chem 279: 40729-40736, 2004.

21. Beaman TW, Sugantino M and Roderick SL: Structure of the hexapeptide xenobiotic acetyltransferase from Pseudomonas aeruginosa. Biochemistry 37: 6689-6696, 1998.

22. Wigley DB, Derrick JP and Shaw WV: The serine acetyltransferase from Escherichia coli. Over-expression, purification and preliminary crystallographic analysis. FEBS Lett 277: 267-271, 1990.

23. Baecker PA and Wedding RT: Purification of serine acetyltransferase, a component of a multienzyme complex, by immunoadsorption and selective dissociation of the complex. Anal Biochem 102: 16-21, 1980. 